\title{
Yield Gap Analysis, Economics and Adoption of Sesame Cultivation through Front Line Demonstration in Pathankot District of Punjab, India
}

\author{
Amit Kaul", Seema Sharma and Bikramjit Singh \\ Krishi Vigyan Kendra, Pathankot, 145001, Punjab Agricultural University, \\ Ludhiana, 141004, India \\ *Corresponding author
}

\begin{abstract}
A B S T R A C T
\section{Keywords}

Benefit cost ratio,

Front line

demonstration,

Grain yield,

Sesame,

Technology gap

\section{Article Info}

Accepted:

12 August 2020

Available Online:

10 September 2020

Sesame is one of the major oilseed crops cultivated in rainfed areas of India, which plays a major role in supplementing the income of small and marginal farmers of Pathankot district of Punjab state. Total 68 front line demonstrations (FLDs) were conducted on farmer's field in Pathankot district for three consecutive years (2017-18 to 2019-20) in two blocks. Prevailing farmer's practices were treated as control for comparison with demonstrated technology. The result of FLDs conducted by Krishi Vigyan Kendra, Pathankot in sesame crop shows a greater impact on farmer's livelihood due to significant increase in yield $\left(551.6 \mathrm{~kg} \mathrm{ha}^{-1}\right)$ over local check $\left(365.3 \mathrm{~kg} \mathrm{ha}^{-1}\right)$. The extension gap ranged between 71.0 to $294 \mathrm{~kg} \mathrm{ha}^{-1}$, whereas the trend of technology gap ranged between 31 to $253 \mathrm{~kg}$ $\mathrm{ha}^{-1}$. The benefit cost ratio (B: C) was recorded higher under demonstrated practice (4.05), while it was 2.27 under check. The results of improved technological intervention brought out $33.77 \%$ increase in yield of sesame. The overall adoption level of demonstrated sesame production technology was increased about $399.5 \%$ due to the adoption of package and practices are followed.
\end{abstract}

\section{Introduction}

Sesame (Sesamum indicum L.) is an ancient oilseed crop grown in India which is the largest producer of this crop in the world. Sesamum (Sesamum indicum L.) are flowering plants, which are cultivated in the tropical regions and is widely cultivated for the edible seeds. Sesame is called as queen of oilseed crops by virtue of its excellent oil quality. It is having the highest oil content (46-64\%) and dietary energy $\left(6355 \mathrm{k} \mathrm{calkg}^{-1}\right)$. It is used as a very common ingredient in the foods all over the world. Sesame crop can be grown in wide range of environments, extending from semiarid tropics and subtropics regions. It is mostly cultivated under rainfed conditions on marginal and submarginal lands with sub-optimal rate of fertilizer and poor management practices. Sesame is grown in areas rainfall of 625$1100 \mathrm{~mm}$ and temperature of $>27^{\circ} \mathrm{C}$. The crop is tolerant to drought, but not to water logging. This probably indicates a great opportunity for a higher increase in sesame productivity in India. India ranks first in terms 
of sesame growing area (23\%). In India, sesame is grown in 1784 lakh ha with an annual production of $850 \mathrm{M}$ tonne and productivity of $486 \quad \mathrm{~kg} \quad \mathrm{ha}^{-1}$ (www.indiastatcom, 2015-16). Though India is the largest producer and exporter of sesame in the world, the productivity is only $250 \mathrm{~kg}$ ha $^{-1}$ (Puspha et al., 2003). The main reason for low productivity of sesame is use of low yielding varieties (local), poor soil fertility and imbalanced nutrition (Engoru and Bashaasha, 2001). The oilseeds scenario in the country has undergone a sea change. The main contributors to such transformation are availability of improved oil seeds production technology along with its adoption and expansion of cultivated area. The improved technology packages were found to be financially attractive. Yet, adoption levels for several components of the improved technology were low emphasizing the need for better dissemination (Kiresur et al., 2001).

Sesame constitutes nearly 11 per cent of the area and four per cent of the total oilseed production in the Punjab state and is the third important oilseed crops after rapeseed/mustard and sunflower, grown in Punjab. The area under sesame declined from 25.6 thousand hectares in 1966-67 to 13.4 thousand hectares in 1989-90 and further to 10.6 thousand hectares in 2004-05 (Statistical Abstracts of Punjab, 2005). The sesame production is concentrated in the districts of Amritsar, Ferozepur, Gurdaspur, Hoshiarpur and Pathankot. In Punjab, with more than 75 per cent of its production base (Grover and Singh,2007). The productivity level of sesame in the Amritsar and Ferozepur districts is above the state average, but the overall state average productivity of the crop has been almost stagnant over the years, reflecting inadequate research efforts made for the upliftment of sesame in the state (Grover and Singh, 2007). Sesame is also cultivated by the farmers belonging to the rainfed areas of
Pathankot district but with local varieties and poor management practices leading to low yield of crop than average. The extent of adoption of improved agricultural technologies is a crucial aspect under innovation diffusion process and the most important for enhancing agricultural production at a faster rate. Large number of technologies evolved in the field of agriculture is not being accepted and adopted to its fullest extent by the farmers. The gap between recommendations made by the scientists and actual use by farmers is frequently encountered (Rohit and Singh, 2019). With the start of Cluster, frontline demonstrations, frontline demonstration on kharif oil seed crops using new crop production technology was started with the objectives of sowing the production potential of the new technologies under real farm situation over the locally cultivated oilseed crops. Total sixty eight frontline demonstrations were conducted by Krishi Vigyan Kendra, Pathankot in different villages of rainfed areas of Pathankot district. The main objective of FLD is to demonstrate the crop production technologies and management practices in the farmers' field under different agro-climatic regions and farming situations.

\section{Materials and Methods}

The present study was conducted by Krishi Vigyan Kendra, Pathankot of Punjab Agricultural University, Ludhiana across two blocks of the district viz. Pathankot and Dhar Kalan during kharif 2017-18 and 2018-19, but during 2019-20 it was conducted in dhar kalan block only. During the entire course of study, a total of 68 farmers were selected for conducting Cluster front line demonstrations of sesame on 30 hectare area. The crop raised by farmers following their own practices was taken as local standard check. Whereas, for front line demonstration plots an integrated 
crop management approach was demonstrated to farmers.

In this approach, all the practices demonstrated to farmers starting from quality seed to fertilizer, weed, insects and disease management were according to recommended package of practices. The crops were harvested at maturity stage with suitable method. To accomplish the integrated approach of demonstrations, KVK scientists conducted various monitoring visits on farmer fields. In addition to this, these visits were helpful in providing valuable feedback from different farmers that can be utilized for further improvement in research and extension programmes. Other extension activities including training programmes, exhibitions, group meetings and Field days were also organized at the demonstration sites to create awareness among the farming community of neighbouring areas about the advantages of demonstrated technologies.

To know the status of soil health, soils samples from each demonstration were collected and various parameters of soil like $\mathrm{pH}, \mathrm{EC}, \mathrm{OC}(\%)$, available $\mathrm{N}, \mathrm{P}$ and $\mathrm{K}$ were analyzed. Soil test results were helpful in need based application of all the three essential nutrients of $\mathrm{N}, \mathrm{P}$ and $\mathrm{K}$. The data on yield were collected through field observations. Gross return was calculated by multiplying yield with the current market price of the sesame crop. Whereas, For calculating input cost, the total sum of expenditure including land preparation, planting method, fertilizer, insecticide, fungicide, herbicide, irrigation cost, labour, harvesting cost, etc. were taken from each demonstration. Further, net return and benefit cost were calculated from these data. Potential yield of chickpea crop in Punjab is $700 \mathrm{~kg}$ ha ${ }^{1}$ To estimate the technology gap, extension gap and the technology index the formulae used (Samui et al., 2000) are as follows:
Technology Gap = Potential yield Demonstration plot average yield

Extension Gap $=$ Demonstration plot average yield - Farmer's plot average yield

Technology Index = (P-D) / P X 100

Where,

$\mathrm{P}=$ Potential yield of the crop

$\mathrm{D}=$ Average demonstration plot yield of the crop

A comparative analysis of the package and practices in demonstration plot and local check is given in Table 1.

The soils of the area are mostly sandy loam in texture. To know the status of soil health, soils samples from each demonstration were collected and various parameters of soil like $\mathrm{pH}, \mathrm{EC}, \mathrm{OC}(\%)$, available $\mathrm{N}, \mathrm{P}$ and $\mathrm{K}$ were analysed. Soil test results were helpful in need based application of all the three essential nutrients of $\mathrm{N}, \mathrm{P}$ and $\mathrm{K}$. In Pathankot block the average $\mathrm{pH}$ of soils was 7.5 with electrical conductivity of $0.38 \mathrm{dSm}^{-1}$. The average organic carbon, available phosphorus and available potassium was0.39\%, 14.6 and 46.8 $\mathrm{kg} \mathrm{ha}^{-1}$, respectively. Similarly, the soils of Dhar kalan block were normal in reaction with $\mathrm{pH}$ of 6.7 and electrical conductivity was $0.58 \mathrm{dSm}^{-1}$. The average organic carbon, available phosphorus and available potassium of Dhar kalan was $0.58 \%, 21.6$ and $56.0 \mathrm{~kg}$ $\mathrm{ha}^{-1}$, respectively. The temperatures generally remains between $35{ }^{\circ} \mathrm{C}$ to $45{ }^{\circ} \mathrm{C}$ during summer and $7{ }^{\circ} \mathrm{C}-15{ }^{\circ} \mathrm{C}(\max )$ to $0{ }^{\circ} \mathrm{C}$ to 8 ${ }^{\circ} \mathrm{C}$ (min) in winters.

\section{Results and Discussion}

\section{Grain yield}

The data in Table 1 indicates that the average grain yield of sesame was higher in 
demonstration plots $\left(551.6 \mathrm{~kg} \mathrm{ha} \mathrm{ha}^{-1}\right)$ in comparison with average grain yield of check plots (365.3 kg ha ${ }^{-1}$ ) during the course of study. Further, there was 33.77 per cent increase in yield of demonstration plots as compared to farmer's practice (Table 1). These results are in agreement with the findings of Meena (2017); Purushottam et al., (2012); Narwale et al., (2009) who have reported similar results of higher yield of demonstration plots in comparison with check plots. In addition to overall average yield, the yield of sesame was higher in comparison to check within clusters. Among the different demonstration plots, maximum yield was obtained in the second cluster of dhar kalan block $\left(669,554\right.$ and $\left.512 \mathrm{~kg} \mathrm{ha}^{-1}\right)$ during 2017 , 2018 and 2019, respectively. Again in the check plots, maximum yield was obtained in the second cluster of dhar kalan block ( 375 and $382 \mathrm{~kg} \mathrm{ha}^{-1}$ ), as compared to first cluster of Pathankot block (371 and 376kg ha-1) during 2017 and 2018, respectively. This data clearly indicated the higher yield of demonstration practices over farmer's local practices .Meena et al., (2018) also reported that the yield of sesame was higher in front line demonstrations with the adoption of high yielding variety as compared to the local check. This increased yield of demonstration plot from check plots is attributed to the use of all the farming practices like sowing time, fertilizer application, plant protection measures according to the recommended package of practices. Grain yield data clearly indicated that FLD programme had a positive impact over the existing practices in enhancing the crop productivity. Kirar et al., (2005) also reported higher productivity in demonstration plots as compared to control. Among the other factors that contributed to lower yield of check plots following farmer's own practices include early sowing of sesame crop that led to susceptibility of sesame tophyllody disease due to which yield was significantly decreased in check as compared to demonstration plot. The higher results obtained from front line demonstrations triggered other farmers to adopt recommended farming practices and the new technologies.

\section{Technology gap}

The technology gap indicates the gap between the demonstrations yield and potential yield. In Punjab, potential yield of sesame is $700 \mathrm{~kg}$ $\mathrm{ha}^{-1}$. The average of three years indicated that the technology gap in Pathankot district was $148.4 \mathrm{~kg} \mathrm{ha}^{-1}$ (Table 1). Whereas, technology gap in district was $57.5,199.5$ and $188.0 \mathrm{~kg}$ $\mathrm{ha}^{-1}$ during 2017, 2018 and 2019, respectively. The technology gap was higher in Pathankot block (84.0 and $253.0 \mathrm{~kg} \mathrm{ha}^{-1}$ ) as compared to Dhar kalan block (31.0 and $146.0 \mathrm{~kg} \mathrm{ha}^{-1}$ ) during 2017 and 2018, respectively. This technology gap may be due to the differences in the fertility status of soil and weather conditions Rao and Ramana, 2017.Mukharjee (2003) have also opined that depending on identification and use of farming situation, specific interventions may have greater implications in enhancing system productivity. To bridge this gap, region specific recommendations are required.

\section{Extension gap}

The variations in yield could be attributed to extension gap. The extension gap of $186.3 \mathrm{~kg}$ $\mathrm{ha}^{-1}$ was found in Pathankot district of Punjab. In the two blocks, highest extension gap of 294.0 and $172.0 \mathrm{~kg} \mathrm{ha}^{-1}$ was recorded in second cluster of Dhar kalan as compared to the first cluster $\left(245.0\right.$ and $\left.71.0 \mathrm{~kg} \mathrm{ha}^{-1}\right)$ during 2017 and 2018, respectively. During the year 2017, the extension gap in block Pathankot was $245.0 \mathrm{~kg} \mathrm{ha}{ }^{-1}$ which was decreased to $71.0 \mathrm{~kg} \mathrm{ha}^{-1}$ during 2018. The highest extension gap in this block during 2017 emphasized the need to educate the farmers through various means for the 
adoption of improved varieties which results in decreased extension gap during the year 2018. However, the extension gap in Dhar block was not decreased upto that extent which showed that there are enormous prospects for different extension activities in the area.

Massive awareness through campaigning and print media like folder and leaflets was done which results in decreasing trend of extension gap in Dhar kalan block (157.0 kg ha-1) during the year 2019.Meena et al 2018 also reported that the new technologies adopted in front line demonstrations along with the awareness campaigning helped in decreasing the extension gap.

\section{Technology index}

The technology index indicates the feasibility of new technology at the farmer's fields and lower the value of technology index, more is the feasibility of the technology (Jeengar et al., 2006).

The average technology index was 21.20 percent in Pathankot district (Table 1). The technology index was less in Dhar kalan block during 2017 and 2018 as compared to Pathankot block. The results are in conformity with the findings of Naik et al., (2016).The wider gap in technology index (ranging between 4.42-26.85 per cent) during the study period in a region may be attributed to the difference in soil fertility status, weather conditions.

This showed that the FLD programme was found to be useful in imparting knowledge and adoption level of farmers in various aspects of sesame production technologies. The results are in conformity with the findings of Rohit and Singh (2019).

\section{Economic return}

The economics of sesame production under front line demonstration have been presented in Table 2. The economic viability of improved demonstrated technology over farmers practice was calculated depending on prevailing price of inputs and output cost and represented in term of benefit cost ratio (B: C ratio).

The cost of production of sesame was varied from Rs 12,500 to 13000 per hectare with an average of Rs 12833.3 per hectare as against Rs 11,800 to 12,500 per hectare with an average of Rs 12,266.6 per hectare under control. The additional cost increased in check plots was due to the use of 2-3 unrecommended pesticides for insect control by the farmers.

Table.1 Existing farmer's practices and improved practices demonstrated in frontline demonstrations at farmer's field in Pathankot

\begin{tabular}{|c|c|c|c|}
\hline S. No. & Operations & $\begin{array}{ll}\text { Existing } & \text { Farmers } \\
\text { Practices } & \end{array}$ & Improved Recommended Practices \\
\hline 1 & Variety & Local & Punjab Til No.2 \\
\hline 2 & Time of Sowing & June - July & First fortnight of July \\
\hline 4 & Method of Sowing & Broad casting & Broadcasting \\
\hline 5 & $\begin{array}{ll}\text { Plant } & \text { Protection } \\
\text { Measures } & \end{array}$ & $\begin{array}{l}\text { Non-adoption of } \\
\text { recommended package of } \\
\text { practices and injudicious } \\
\text { use of pesticides. }\end{array}$ & $\begin{array}{l}\text { Adopted recommended package of } \\
\text { practices for sesame crop developed } \\
\text { by Punjab Agricultural University, } \\
\text { Ludhiana }\end{array}$ \\
\hline
\end{tabular}


Table.2 Yield, technology gap, extension gap and technology Index of Sesame in District Pathankot

\begin{tabular}{|c|c|c|c|c|c|c|c|c|c|c|}
\hline \multirow[t]{2}{*}{ Year } & \multirow{2}{*}{$\begin{array}{l}\text { Blocks of district } \\
\text { Pathankot }\end{array}$} & \multirow{2}{*}{$\begin{array}{l}\text { No. of } \\
\text { Clusters }\end{array}$} & \multirow{2}{*}{$\begin{array}{c}\text { Total no. of } \\
\text { demonstrations }\end{array}$} & \multicolumn{3}{|c|}{ Yield (kg ha $\left.{ }^{-1}\right)$} & \multirow{2}{*}{$\begin{array}{l}\% \text { increase } \\
\text { over check }\end{array}$} & \multirow{2}{*}{$\begin{array}{l}\text { Technology } \\
\text { gap } \\
\left(\mathrm{kg} \mathrm{ha}^{-1}\right)\end{array}$} & \multirow{2}{*}{$\begin{array}{c}\text { Extension } \\
\text { Gap } \\
\left(\mathrm{kg} \mathrm{ha}^{-1}\right)\end{array}$} & \multirow{2}{*}{$\begin{array}{l}\text { Technology } \\
\text { Index }(\%)\end{array}$} \\
\hline & & & & Potential & Demonstration & Check & & & & \\
\hline \multirow[t]{2}{*}{ 2017-18 } & Pathankot & I & 14 & 700 & 616.0 & 371.0 & 39.12 & 84.0 & 245.0 & 12.0 \\
\hline & \multicolumn{2}{|c|}{ Blocks Total/Average } & 20 & 700 & 642.5 & 373.0 & 41.94 & $\mathbf{5 7 . 5}$ & 269.5 & 8.21 \\
\hline \multirow[t]{2}{*}{ 2018-19 } & Pathankot & I & 15 & 700 & 447.0 & 376.0 & 14.54 & 253.0 & 71.0 & 36.14 \\
\hline & Dhar kalan & II & 8 & 700 & 554.0 & 382.0 & 32.12 & 146.0 & 172.0 & 20.85 \\
\hline 2019-20 & Dhar kalan & I & 25 & 700 & 512.0 & 355.0 & 30.66 & 188.0 & 157.0 & 26.85 \\
\hline \multicolumn{3}{|c|}{ Total/Average } & 68 & 700 & 551.6 & 365.3 & 33.77 & 148.4 & 186.3 & 21.20 \\
\hline
\end{tabular}

Table.3 Gross return, Cost of cultivation, net return and B:C ratio of sesame in district Pathankot

\begin{tabular}{|c|c|c|c|c|c|c|c|c|c|c|}
\hline \multirow[t]{2}{*}{ Year } & \multirow{2}{*}{$\begin{array}{c}\text { Blocks of } \\
\text { district } \\
\text { Pathankot }\end{array}$} & \multirow[t]{2}{*}{$\begin{array}{c}\text { No. of } \\
\text { Clusters }\end{array}$} & \multicolumn{2}{|c|}{$\begin{array}{l}\text { Gross Return } \\
\quad\left(\text { Rs. ha }{ }^{-1}\right)\end{array}$} & \multicolumn{2}{|c|}{$\begin{array}{c}\text { Cost of cultivation } \\
\left(\text { Rs. }^{\text {ha }}{ }^{-1}\right)\end{array}$} & \multicolumn{2}{|c|}{$\begin{array}{l}\text { Net Return } \\
\left(\text { Rs. ha }{ }^{-1}\right)\end{array}$} & \multicolumn{2}{|c|}{ B:C ratio } \\
\hline & & & Demonstration & Check & Demonstration & Check & Demonstration & Check & Demonstration & Check \\
\hline \multirow{3}{*}{$\begin{array}{l}2017- \\
18\end{array}$} & Pathankot & I & 49,280 & 30,000 & 11,800 & 12,500 & 37,480 & 17,500 & 4.17 & 2.40 \\
\hline & Dhar Kalan & II & 53,520 & 29,680 & 11,800 & 12,500 & 41,720 & 17,500 & 4.53 & 2.37 \\
\hline & \multicolumn{2}{|c|}{ Block Total/Average } & 51,400 & 29,840 & 11,800 & 12,500 & 39,600 & 17,500 & 4.35 & 2.38 \\
\hline \multirow{3}{*}{$\begin{array}{l}2018- \\
19\end{array}$} & Pathankot & I & 40,230 & 30,560 & 12,500 & 13,000 & 27,730 & 17,000 & 3.22 & 2.35 \\
\hline & Dhar Kalan & II & 49,860 & 30,080 & 12,500 & 13,000 & 37,360 & 17,000 & 3.98 & 2.31 \\
\hline & \multicolumn{2}{|c|}{ Block Total/Average } & 45,045 & 29,440 & 12,500 & 13,000 & 32,545 & 17,000 & 3.60 & 2.31 \\
\hline $\begin{array}{l}2019- \\
20\end{array}$ & Dhar Kalan & I & 46,080 & 31,950 & 12,500 & 13,000 & 33,580 & 20,750 & 3.68 & 2.45 \\
\hline \multicolumn{2}{|c|}{ Total/Average } & & 49,644 & 29,224 & $12,266.6$ & $12,833.3$ & 37,377.4 & $16,390.7$ & 4.05 & 2.27 \\
\hline
\end{tabular}


Table.4 Impact of Front Line Demonstration (FLDs) on adoption of Sesame production technology

\begin{tabular}{|c|c|c|c|c|}
\hline Technology & \multicolumn{2}{|c|}{ Number of Adopters $(\mathrm{N}=68)$} & \multirow{2}{*}{$\begin{array}{c}\text { Change in No. } \\
\text { of Adopter }\end{array}$} & \multirow{2}{*}{$\begin{array}{c}\text { Impact } \\
(\% \\
\text { Change })\end{array}$} \\
\hline $\begin{array}{l}\text { Land preparation and FYM } \\
\text { application }\end{array}$ & $\begin{array}{c}\text { Before } \\
\text { Demonstration }\end{array}$ & $\begin{array}{c}\text { After } \\
\text { Demonstration }\end{array}$ & & \\
\hline Recommended variety & 14 & 68 & 65 & 385.7 \\
\hline Seed rate & 12 & 68 & 56 & 466.6 \\
\hline Sowing time/sowing method & 17 & 68 & 61 & 258.8 \\
\hline Balance Fertilizer & 9 & 68 & 59 & 655.5 \\
\hline Weed Management & 32 & 68 & 36 & 112.5 \\
\hline $\begin{array}{l}\text { Recommended Insect pest } \\
\text { management }\end{array}$ & 11 & 68 & 57 & 518.2 \\
\hline \multicolumn{4}{|c|}{ Overall Impact } & 399.5 \\
\hline
\end{tabular}

The data revealed that the gross return from the demonstration were substantially higher than control plots. Higher average gross return was observed in demonstration plots (Rs. 49,644 $\mathrm{ha}^{-1}$ ) in comparison with check plots (Rs. 29,224 ha ${ }^{-1}$ ). Whereas, among demonstrations within two blocks, higher gross return (Rs. 53,520 and Rs 49,860 ha ${ }^{-1}$ ) were observed in Dhar kalan block as compared to the first cluster of Pathankot block (Rs. 49,280and Rs 40,230 ha ${ }^{-1}$ ) during 2017 and 2018, respectively. Also, the average net returns were higher under demonstration plots (Rs 37,377.4 $\mathrm{ha}^{-1}$ ) as compared to check plot (Rs. 16,390.7 ha ${ }^{-1}$ ).

Similar observations of higher returns in demonstration plots as compared to farmer's practice have been reported by Singh et al., (2014); Bhargav et al., (2017). B: C ratio was recorded to be higher under demonstration against check during all the years of study (Table 2). Scientific method of sesame cultivation can reduce the technology gap to a considerable extent, thus leading to increased productivity of sesame in the district which in turn will improve the economic condition of the growers. Tomar (2010); Meena and Dudi (2012) have also reported higher benefit from demonstration plots (Table 3 ).
The results of improved technological intervention brought out an increase in yield of sesame to the tune of 14.54 to $44.54 \%$ (Table 4). Improved package of practices can decrease the technology gap, thereby productivity of the crop can be increased. It was found that adoption of recommended variety of sesame by the farmers before demonstration was negligible, which increased by $399.5 \%$ after demonstration. Therefore, target oriented training programme on improved sesame production technology along with multiple demonstrations is required to enhance level of knowledge and skills of growers which ultimately lead to adoption of technologies. Singh et al 2018 also reported that the adoption of appropriate package and practices in FLD's increased the adoption level of production technology.Sesame cultivation and adoption of new technologies enhanced sesame seed/oilseed consumption nutritional security and overall livelihood security of the district.

In conclusion the results of front line demonstration programme showed that the farmers can achieve higher yields and net profit in sesame cultivation by adopting recommended practices. Technological and extension gaps may be filled by the efforts of extension agencies through popularizing 
package of practices, advisory services, field visits and by organizing exhibitions and field days. Replacement of local farmer's practice and local varieties would be another viable option to enhance the production as well as net returns from sesame crop.

\section{References}

Anonymous, 2005 Statistical Abstract of Punjab. Economic and Statistical Organisation of Punjab, Chandigarh.

Bhargav, K. S., Khedkar N. S., Verma G., Ambawatia G. R., Gupta N. and Patel N. 2017. Evaluation of Front Line Demonstration on Chick Pea in Shajapur District of MP. Int J Pure and Applied Biosci.5: 293-297.

Engoru P. and Bashaasha B. 2001.Constraints to the effective production and marketing of sesame.African Crop Science Conference Proceedings, Soroti, Uganda, 5th November 1998.p. 715.

Grover,D. K. and Singh,J. M. 2007.Sesamum Cultivation in Punjab: Status, Potential and Constraints.Agric Econ Res Review. 20 299-313.

Jeengar, K. L., Panwar P. and Pareek, O. P. 2006. Front Line Demonstration on Maize in Bhilwara district of Rajasthan. Current Agric., 30 (1-2): 115-116.

Kirar BS, Mahajan SK, Nashine R, Awasthi AK, Shukla RK. 2005. Impact of technological Practices on the Productivity of soybean in front line demonstration. Ind. Res. J. of Extn. Edn.5: 1.

Kiresur V. R., Rumana Rao S. V., Hedge DM. Improved Technologies on Oilseeds Production - An Assessment of their Economic Potentials in India. Agric. Eco. Res. Rev. 2001; 14:95-108.

Meena M L. 2017. Effect of Front Line Demonstrations of Chickpea Cv. RSG-
888 on Farmers' Field in Rainfed Condition of Rajasthan, India. Asian $J$ Agric Ext, Econ \&Socio18: 1-7.

Meena M. L., Dudi A. 2012. On farm testing of chickpea (Cicer arietinumL.) cultivation for site specific assessment under rainfed condition of western Rajasthan. Indian J Ext Edu.48:93-97.

MeenaRamkishan, Singh Bacchu, Meena K.C., Meena R.K., Singh B. and GurjarPrakash. 2018. Performance of Front Line Demonstrations on Sesame (Sesamum indicum L.) in Karauli District of Rajasthan, India. Int.J. Curr. Microbiol. App. Sci.7 (3): 1507 1511

Mukharjee N. 2003. Participatory Learning and Action.Concept Publishing Company, New Delhi India. pp 63-65.

Naik A., Patil D. H., Raju, TeggelliG. and Zaheer A. B. 2016. Productivity enhancement of sesame (Sesamum indicum L.) through improved production technologies/ frontline demonstrations. Res. Environ. Life Sci.9(5): 573-574

Narwale SS, Pawar AD, Lambade BM, Ugle NS. 2009. Yield maximization of chickpea through INM applied to sorghum-chickpea cropping sequence under irrigated condition. Legumes Res., 4: 282-285.

Purushottam Singh S. K, Chaudhary R. N., Kumar K., Praharaj C. S., Krishana B. 2012. Assessment of technological inputs for major pulses in Bundelkhan region. J Food Legumes, 25:61-65.

Puspha, R. and Senthilkumar, P. 2003. Studies on the combining ability in Sesame (S. indicum L.) Paper presented in the National Seminar on Advances in Genetics and Plant breeding - Impact of DNA revolution. October 30-31, University of Agricultural Sciences, Dharwad, Karnauika, India (2003). 
Rao, V. G. and Ramana, P. V. 2017.Introduction of Sorghum New Variety CSV-15 in Agency tracts of East Godavari of Andhra Pradesh. Global J. Biosci. Biotech., 6(2): 366368.

Rohit and Jitendra Singh (2019) Impact of front line demonstrations on sesame (Sesamum indicum L.) in Agra district of U.P.J Pharmacognosy \& Phytochem., 2019; 8(6): 339-341

Samui SK, Roy DK, Mandal AK, Saha D. 2000.Evaluation of Front Line demonstration on groundnut. $J$ Indian Soc. Costal Agric. Res., 18:180-183.
Singh N. K., Singh Mrigendra, Bisen Sharad and Bhandarkar A.P. 2018. Yield Gap Analysis, Economics, Adoption and Horizontal Spread of Tomato Cultivation through Front Line Demonstration in Seoni District of Madhya Pradesh, India. Int. J. Curr. Microbiol. App. Sci., 7(5): 2720-2726.

Tomar R. K. S., Sahu B. L., Singh A. K., Prajapati R. K. 2009. Productivity enhancement of blackgram through improved production technologies in farmers' field. J Food Legumes, 22:202-204.

\section{How to cite this article:}

Amit Kaul, Seema Sharma and Bikramjit Singh. 2020. Yield Gap Analysis, Economics and Adoption of Sesame Cultivation through Front Line Demonstration in Pathankot District of Punjab, India. Int.J.Curr.Microbiol.App.Sci. 9(09): 1536-1544.

doi: https://doi.org/10.20546/ijcmas.2020.909.194 